Araştırma Makalesi / Research Article

\title{
II. Abdülhamid Devrinde Kâğıthane Mesiresi
}

\section{Fırat Küskü*}

(ORCID ID: 0000-0003-4980-6219)

\section{Gönderim Tarihi \\ (Submitted)}

18.06.2020

\author{
Kabul Tarihi \\ (Accepted) \\ 19.08.2020
}

\author{
Yayın Tarihi \\ (Published)
}

30.09 .2020

\section{Atıf Bilgisi/Reference Information}

Chicago: Küskü, F., "II. Abdülhamid Devrinde Kâğıthane Mesiresi", VakanüvisUluslararası Tarih Araştırmaları Dergisi, 5/2 (2020): 841-867.

APA: Küskü, F. (2020). II. Abdülhamid Devrinde Kâğıthane Mesiresi. VakanüvisUluslararası Tarih Araştırmaları Dergisi, 5 (2) , 841-867.

Öz

Kâğıthane mesiresi, 14. yüzyıldan itibaren, Osmanlı Devleti'nin önemli bir gezinti ve eğlence merkezi olarak öne çıkmaktadır. Henüz 15. yüzyılda dillere destan güzelliğinin eserlere yansıdığını tespit edebildiğimiz semt, Lale Devri olarak adlandırılan III. Ahmet'in saltanatı sırasında en parlak dönemini yaşamıştır. Uzun yıllar boyunca eğlence merkezi olarak hem yurtiçinden hem de yurtdışından gelen misafirlerin uğrak yeri olmayı başaran semt, önemini 20. yüzyıla kadar muhafaza etmiştir. Makalede mesirenin tarihine kısaca atıfta bulunulduktan sonra Sultan II. Abdülhamid dönemi (1876-1909) incelenmiştir. Bu dönemdeki Kâğıthane mesirelerinden insan manzaraları aktarılarak canlı bir Kâğıthane portresi çizilmeye çalışılmıştır. Ayrıca Sultan II. Abdülhamid'in, şehzadelik döneminden itibaren semte olan yaklaşımı ve semt özelindeki faaliyetleri arşiv belgelerine dayanarak aktarılmıştır.

Anahtar Kelimeler: Kâğıthane Mesiresi, Sâdâbâd Eğlenceleri, Sultan II. Abdülhamid, Osmanlı'da Eğlence, Lale Devri.

\footnotetext{
* Arş. Gör., Sinop Üniversitesi, Fen-Edebiyat Fakültesi Tarih Bölümü, Türkiye, firatkusku@gmail.com.

Research Assistant, Sinop University, Faculty of Arts and Sciences, Department of History, Turkey.
}

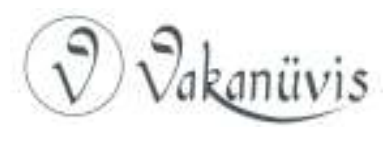




\title{
Kagithane Promenade In The Period Of Sultan Abdulhamid II
}

\begin{abstract}
Kagithane promenade stands out as a recreation and entertainment center since the 14 . century. The neighborhood where we see its beauty reflected in the books in the early 15th century was peaked in the period of Ahmet III, called the Tulip Period. For many centuries, it has managed to be the focus of both domestic and international guests as an entertainment center. Its importance was preserved until the 20th century. In the article, the period of Sultan Abdulhamid II (1876-1909) was studied. It was attempted to draw a portrait of Kagithane by showing human portraits from Kagithane. The approach of the Sultan is studied from the time when he was a prince. And his activities in the district while he was the Sultan were explained based on the archive documents.
\end{abstract}

Keywords: Kagithane Promenade, Sadabad Entertainment, Abdulhamid II, Ottoman Entertainment, Tulip Era.

\section{Giriş}

İsmini bölgede bulunan kâğıt imalathanelerinden alan Kâğıthane semti, ${ }^{1}$ Haliç'e dökülen bir derenin ${ }^{2}$ kıyısındaki güzel konumu ile yüzyıllar boyunca bir gezinti ve mesire yeri olarak öne çıkmaktadır. Semtte kâğıt imalatının yanı sıra baruthaneler de bulunmaktadır. ${ }^{3}$ Ancak Kâğıthane'nin sahip olduğu ün ne kağıthaneler ne de baruthaneler sayesindedir. Kâğıthane'nin barındırdığı doğal güzellikler ve bir mesire yeri olarak öne çıkması bu şöhreti beraberinde getirmiştir. Osmanlı'nın erken devirlerinden, bilhassa İstanbul'un fethinden itibaren Kâğıthane'nin dillere destan güzelliği muhtelif eserlere yansımıştır. ${ }^{4}$

\footnotetext{
${ }^{1}$ Hüseyin Irmak, Illk Çağdan Günümüze Kağıthane, Kağıthane Belediyesi Kültür Yayınları, C. I, İstanbul 2018, s. 15.

2 "Haliç'e dökülen Kâğıthane Deresi (Barbyses) kuzeyden akar." Dionysios Byzantios, Deniz Yoluyla Boğaz, (Çev. Erendiz Özbayoğlu), TB Yayıncılık, İstanbul 2009, s. 57.

3 P. G. İnciciyan, XVIII. Asırda İstanbul, (Çev. Hrand D. Andreasyan), İstanbul Enstitüsü Yayınları, İstanbul 1956, s. 78.

${ }^{4}$ Kâğıthane ile ilgili şiir yazan ilk kişi Amasyalı devlet adamı ve şair Tâcizade Cafer Çelebi (1452-1515)'dir. "Geniş Sahrası çevre yanı kühsâr, Dırahtistân-ü sebzistân-ü gülzâr." Ahmet Refik, Kafes ve Ferace Devrinde Istanbul, (Haz. Tahir Yücel), Kitabevi, İstanbul 1998, s. 81.
}

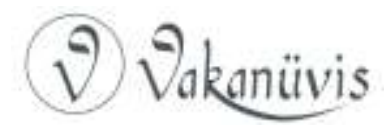


Kâğıthane'nin yüzyıllar boyunca bir eğlence merkezi olarak öne çıkmasının temelinde, III. Ahmed devrinde (1703-1730) Kâğıthane deresinin iki yanına kurulan ve "Sâdâbâd" olarak adlandırılan yapılar topluluğu ve şair Nedim'in ${ }^{5}$ buraları tasvir eden şiirleri vardır. ${ }^{6}$ Birçok saray, köşk, konak, çeşme ve çeşitli binalardan oluşan bu mekân, bir mesire ve eğlence yeri olarak Lale Devri' $\operatorname{nin}^{7}$ sembollerinden olmuştur. Patrona Halil İsyanı'nda bu yapıların birçoğunun yıkılması ve Lale Devri'nin sona ermesiyle eski önemini kaybeden semt, yine de Osmanlı Devleti'nin yıkılışına kadar birçok edebi esere, ${ }^{8}$ seyahatnamelere, hatıratlara ve arşiv belgelerine konu olmuş, Dersaadet'in önde gelen mesire ve eğlence yeri olarak varlığını muhafaza etmiştir. ${ }^{9}$

17. yüzyılda en parlak dönemini yaşayan semt, yetiştirdiği laleler ile "Lalezar Mesiresi" olarak da anılmıştır. Yalnız lale değil, çok yararı bir bitki olan eğir otu da burada yetişmiştir. Deresi oldukça temiz ve berrak olduğu için hem serinlemek isteyenler hem de çamaşır yıkayanlar için bulunmaz bir yer olmuştur. Ayrıca "su tiryakileri" ${ }^{10}$ için de içme suyu oldukça lezzetli ve tercih edilen sular arasında yer almıştır. ${ }^{11}$ Sularının

5 "Istanbul'un şu yeni yapılmış Sâdâbâd'ına bak suyu ve havası insanın canına can katar, insan cedvel-i sim içinde bir kayığa binse eğer isterse cennetin ta yanına varabilir." Hasibe Mazıoğlu, Nedim, Kültür ve Turizm Bakanlığı Yayınları, Ankara 1988, s. 99.

6 Banu Bilgicioğlu, "Sâdâbâd", Türkiye Diyanet Vakfı İslam Ansiklopedisi (DiA), c. 35, İstanbul 2008, s. 379-381.

71718 Pasarofça ile 1730 Patrona Halil isyanları arasında barış ile geçen ve çeşitli eğlenceler ile renklenen bu dönem Ahmet Refik Altınay'ın inceleme eserine verdiği isim ile "Lale Devri" olarak meşhur olmuştur. Ayrıntılı bilgi için bkz. Ahmet Refik Altınay - Lale Devri (1718-1730), Tarih Vakfı Yurt Yayınları, İstanbul 2011.

8 II. Abdülhamid devrinin önemli yazarlarından olan Ahmet Mithat Efendi'nin Felâtun Bey ve Râkım Efendi eserinde Kâğıthane mesiresi muhtelif bölümlerde anlatılmıştır. Ayrıntılı bilgi için bkz. Ahmet Mithat Efendi - Felâtun Bey ve Râkım Efendi, (Haz. Emrah Balcı), Türkiye İş Bankası Kültür Yayınları, İstanbul 2019.

${ }^{9}$ Kâğıthane mesiresinin sosyolojik boyutu hakkında ayrıntılı bilgi için bkz. Mitat Tekçam, Osmanlı Eğlence Kültüründe Mesire Yeri Olarak Kağıthane, Sakarya Üniversitesi Sosyal Bilimler Enstitüsü, Yayınlanmamış Yüksek Lisans Tezi, Sakarya 2006.

10 "İyi memba sularının müptelası olan su tiryakileri, tattığı suyun hangi kaynağa ait olduğunu bilecek kadar uzmanlaşmış ..." Davut Hut, "Beykoz'un Meşhur Kaynak Suları: 19 ve 20. Yüzyıllarda Karakulak, Çubuklu, Göztepe ve Sırmakeş Suları Üzerine Bir Değerlendirme", Beykoz 2019 Sempozyumu Tebliğler Kitabı, Beykoz Belediyesi Kültür Yayınları: 35, İstanbul 2020, s. 308.

${ }^{11}$ Seyit Ali Kahraman, Yücel Dağlı, Günümüz Türkçesiyle Evliya Çelebi Seyahatnamesi: istanbul, Yapı Kredi Yayınları, C. I, K. II, İstanbul 2003, s. 441.

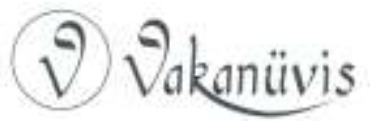


güzelliği nedeniyle burası yabancılar tarafından sıklıkla "Avrupa'nın tatlı suları" ${ }^{12}$ veya "tatlı sular vadisi" ${ }^{13}$ olarak da anılmıştır.

\section{Abdülhamid'in Kâğıthane'ye Yaklaşımı}

Sultan II. Abdülhamid'in Kâğıthane semtine olan ilgisi tahta geçmesinden evvel başlamıştır. ${ }^{14}$ Abdülhamid, şehzadeliği sırasında zamanının büyük çoğunluğunu Kâğıthane'de; ata binmek, atış talimi yapmak, yüzmek, piyano çalmak, bahçıvanlık ve marangozluk işleri ile geçirmiştir. ${ }^{15}$ Kâğıthane Kasr-ı Hümayununda at ile gezinti yapan şehzade, sık sık Kâğıthane deresinde kürek çekmiştir. ${ }^{16}$ Şehzadeliğinin son dönemlerini geçirdiği Maslak Köşkü'ne geçene kadar uzun süre Kâğıthane'de kaldığı da bilinmektedir. ${ }^{17} \mathrm{Bu}$ yüzden, semti daha şehzadeliği döneminden itibaren çok iyi bildiği ve zamanının büyük çoğunluğunu burada geçirdiğinden mütevellit burayı çok sevdiği anlaşılmaktadır.

Abdülhamid'in devr-i saltanatında sıfırdan inşa edilen çok sayıda yapı olduğu gibi restorasyona tabi tutulan yapıların sayısı da bir hayli fazladır. Bu dönemde, semtin simge yapıları başta olmak üzere büyük bir imar faaliyetine girişilmiştir. Illk kez III. Ahmed döneminde inşa edilen ve birkaç kez yıkılıp yeniden yaptırılan, son halini ise Sultan Abdülaziz devrinde alan Sâdâbâd Camii, II. Abdülhamid döneminde restore edilmiştir. ${ }^{18}$ Padişah mesireye gelen insanların ulaşımlarını daha rahat sağlamaları ve toz, toprak, çamur içinde yürümelerinin önüne geçmek için devamlı olarak kaldırımların onarılmasını sağlamıştır. ${ }^{19}$ Yine

\footnotetext{
12 Alexander Van Millingen, Istanbul, (Çev. Aykut Gürçağlar), Alkım Yayınevi, İstanbul 2003, s. 84.

${ }^{13}$ Friedrich Schrader, İstanbul 100 Yıl Öncesine Bir Bakış, (Çev. Kerem Çalışkan), Remzi Kitabevi, İstanbul 2015, s. 174.

${ }^{14}$ II. Abdülhamid'in şehzadeliği ve sultanlığı ile ilgili ayrıntılı bilgi için bkz. Orhan Koloğlu, Abdülhamit Gerçeği, Pozitif Yayıncılık, İstanbul 2005.

${ }^{15}$ François Georgeon, Sultan Abdülhamid, (Çev. Ali Berktay), iletişim Yayınları, İstanbul 2018, s. 38.

${ }^{16}$ Ayşe Osmanoğlu, Babam Sultan Abdülhamid, Timaş Yayınları, İstanbul 2019, s. 39.

17 Vahdettin Engin, Bir Devrin Son Sultanı II. Abdülhamid, Yeditepe Yayınevi, İstanbul 2018, s. 15.

18 Sâdâbâd Camii'nin kurşun kaplamaları yenilenmiştir. Türkiye Cumhuriyeti Cumhurbaşkanlığı Devlet Arşivleri Başkanlığı Osmanlı Arşivi (BOA), İrade Evkaf (i...EV...), 37/44, 05 L 1322/13 Aralık 1904.

${ }^{19}$ BOA, Dâhiliye Mektubî (DH. MKT.), 1824/65, 21 ş 1308/01 Nisan 1891.
}

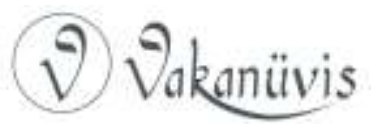


ulaşımın önemli bir parçası olan köprülerin tamiri de muntazam olarak gerçekleşmiştir. Kâğıthane deresi üzerindeki ahşap köprüler ile Sünnet, Mirahor, Taştekneler, Cendere ve Çağlayan köprüleri birkaç kez tamir geçirmiştir. ${ }^{20}$ Meşhur 1894 depreminde ${ }^{21}$ hasar gören Darülferes-i Hümayun ile Çağlayan ve Mirahor Kasr-ı Hümayunları da tamir ettirilmiştir. ${ }^{22}$ Ayrıca Kâğıthane'ye, tıbbi malzemeler gönderilerek, masrafları Hazine-i Hassa'dan karşılanmak üzere bir de hastane yaptırılmıştır. ${ }^{23}$ Hastanenin açılışı da sultanın tahta çıktığı güne denk getirilmiştir. ${ }^{24}$

Illk örneklerine Sultan Abdülmecid döneminde rastladığımı okul gezileri, II. Abdülhamid döneminde artarak devam etmiştir. Sultan, çeşitli mektep öğrencilerine ziyafetler düzenler, bunu duyan halk da akın akın bölgeye giderdi. Özellikle Ramazan ayında iftar münasebetiyle öğrencilerle bir araya gelen Sultan, onların hazırladıkları konuşmaları da dinlerdi. 1893 tarihinde bir iftar organizasyonunda Sultan, muhtelif okullarda okuyan öğrenciler, idareciler, muallimler ve okuldaki diğer memurlarla bir araya gelmiştir. ${ }^{25}$ Sivil ve askeri okullardan birçok öğrencinin katıldığı bu ziyafetler öğrenciler arasında büyük heyecan uyandırırdı. Padişahın huzurunda düzenlenecek olan bu ziyafete katılacak öğrencilere en yeni kıyafetler dağıtılırdı. Baytar Mektebi ve Topçu Mektebi vapur ile Karaağaç'a geçerken Mühendishane-i Berr-i

\footnotetext{
${ }^{20}$ BOA, İrade Şura-yı Devlet (i..ŞD..), 54/3046, 27 C 1298/27 Mayıs 1881; BOA, DH.MKT., 1493/103, 29 C 1305/13 Mart 1888; BOA, Yıldız Resmi Maruzat (Y..A..RES.), 73/43, 13 C 1312/12 Aralık 1894; BOA, DH.MKT., 1503/28, 11 Ş 1305/23 Nisan 1888.

${ }^{21} 1894$ depremi hakkında ayrıntılı bilgi için bkz. Sema Küçükalioğlu Özkılıç, 1894 Depremi ve İstanbul, İş Bankası Kültür Yayınları, İstanbul 2015.

22 BOA, Yıldız Mabeyn Erkanı ve Saray Görevlileri Evrakı (Y..PRK..SGE.), 6/32, 06 M 1312/10 Temmuz 1894.

${ }^{23}$ BOA, Maliye Nezareti Emlak-i Emiriyye Müdüriyeti (ML.EEM.), 320/17, 13 Eylül 1315, 25 Eylül 1899.

24 BOA, ML.EEM., 317/27, 17 Ağustos 1315/29 Ağustos 1899.

${ }^{25} 1893$ tarihli belgeden anlaşıldığına göre II. Abdülhamid 1892 senesinde de aynı şekilde bir ziyafet düzenlemiştir. "Geçen sene Kâğıthane'de verilen ziyafet-i seniyyede bulunan mekteplerin esâmisi ile mikdar-i nüfus ve masarıfını mübeyyin kuyud-ı hazineden terkim olunan bir kıt'a defterin leffen takdimine ibtidâr kılınmış..." Yine bu belgeye göre ziyafete katılan okullar şunlardır: "Mekteb-i Harbiye-i Şâhâne, Mühendishane-i Berri-i Hümâyun, Mekteb-i Fünûn-u Bahriye, Mekteb-i Tıbbiye-i Şahane, Numune-i Terakki Mektebi, Mekteb-i Sanayi, Darüşşafaka Mektebi ve Mekteb-i Mülkiye-i Şahane." BOA, Yıldız Hazine-i Hassa (Y. PRK. HH.), 26/41, 12 L 1310/ 29 Nisan 1893.
}

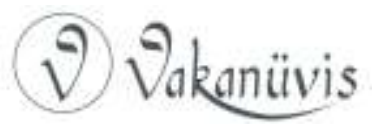


Hümâyun öğrencileriyle orada birleşirlerdi. Kimi yayan kimi arabalarla toz toprak içinde kalarak ziyafet sofrasına varırlardı. Burada genellikle kuzu ve salata yendikten sonra padişahı öven kasideler okunurdu. ${ }^{26}$ Yemek ve kasidelerin ardından ise okullar arası jimnastik oyunları oynanırdı. ${ }^{27}$ Mekteb-i Harbiyye talebeleri ise buraya yalnızca ziyafet günlerinde değil, muallimlerinin eşliğinde uygulamalı dersler ve birtakım sınavlar için de yine Kâğıthane'ye gelirlerdi. ${ }^{28}$

Kâğıthane mesiresinde birtakım oyunlar oynanması ve yarışmalar düzenlenmesi eskiden beri süregelen bir âdetti. Bilhassa Sultan II. Mahmud devrinde, semtte çok sayıda okçuluk yarışması düzenlendiği bilinmektedir. Sultan'ın bizzat ok atarak katıldığı bu müsabakalar halk tarafından ilgiyle takip edilirdi. Padişahın attığı okun mesafesi saray iç oğlanları tarafından belirlenir, paşaların ve diğer katılımcıların padişahı geçmemesi yazısız bir nezaket kuralı olarak uygulanırdı. ${ }^{29} \mathrm{I}$. Abdülhamid devrinde ise okçuluk yarışmalarının yerini at yarışlarının aldığı görülmektedir. Padişahın düzenlediği ziyafetler esnasında yapılan okullar arası yarışmaların yanı sıra, semtte oldukça yüksek katılımlı at yarışları da düzenlenmiştir. Hazırlanan 3500 metrelik koşu pisti; Kâğıthane deresinin yanından Koşu Köşkü’nün önünden ve çarşının arka tarafından geçerken; Koşu Köşkü'nün yanına halkın yarışları takip etmesi için bir tribün de kurulmuştur. ${ }^{30}$ Arap, Anadolu, Rumeli ve Rahvan cinsi atların; cins ve yaşa bağlı olarak farklı kategorilerde yarıştığı bu müsabakaların galiplerine para ödülleri verilmiştir. ${ }^{31}$

\footnotetext{
26 “... taraf-ı ahkeranemden şakirdan kullarına görmekte olduğumuz in'am ve ihsan-ı şahanelerinden dolayı medyun olup bunun için uğur-ı hümayunlarında feda-yı can etsek binde birisinin bile hakkını ödeyemeyeceğimizi mutazammın irad-ı nutuk olunmuş ve bülend-avaz ile padişahım çok yaşa dua-yı mefruzu'l-edası tekrar tekrar tezkar olunmuştur." BOA, Yıldız Askeri Maruzat (Y..PRK.ASK.), 98/45, 16 ZA 1311/21 Mayıs 1894.

27 Sermet Muhtar Alus, Masal Olanlar, (Haz. Nuri Akbayar), İletişim Yayınları, İstanbul 1997, s. 148-152.

28 BOA, Y..PRK..ASK., 174/97, 07 \$̧ 1319/19 Kasım 1901; BOA, Y..PRK..ASK., 176/5, 02 N 1319/13 Aralık 1901.

29 Julia Pardoe, Sultanlar Şehri istanbul, (Çev. M. Banu Büyükkal), Türkiye İş Bankası Kültür Yayınları, İstanbul 2017, s. 227.

${ }^{30}$ BOA, Yıldız Hazine-i Hassa (Y.PRK.HH..), 6/29, 28 R 1297/09 Nisan 1880.

${ }^{31}$ BOA, Yıldız Müteferrik (Y..PRK.M...), 2/72, 29 Z 1305/06 Eylül 1888.
}

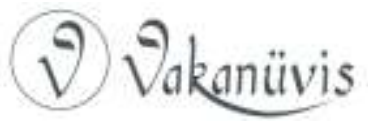


II. Abdülhamid Kâğıthane'yi yalnızca kendi gezintileri için yahut halkın eğlenceleri için değil, uluslararası siyasi meselelerde de kullanmıştır. Öncelikle, Sultan'ın konuğu olarak Dersaadet'te bulunan misafirlerin Kâğıthane'de gezintiye çıkmaları sağlanmıştır. 1897 yılında ziyarete gelen Fransa İmparatoriçesi Eugenie Kâğıthane'yi ziyaret etmiş, Çağlayan Kasrı'nın ardından büyük çarşıda bir saat zaman geçirmiştir. ${ }^{32}$ Kayzer II. Wilhelm de 1889 yılındaki ilk ziyaretinde Kâğıthane ve civarını gezmiştir. ${ }^{33}$ İmparator burayı çok beğeniş olmalı ki döndükten sonra Kâğıthane bahçesine ait bir fotoğraf hediye olarak kendisine gönderilmiştir. ${ }^{34}$ Kâğıthane'den imparatorlara gönderilen hediyeler yalnızca fotoğrafla sınırlı kalmamıştır. Semtte bulunan haradan seçme atlar Almanya, Fransa İmparatorları, Belçika Kralı ${ }^{35}$ ve Mısır Hıdivine gönderilmiştir. ${ }^{36}$

Uluslararası siyasi konularda Kâğıthane semtinin kullanımına ilişkin bir diğer örnek ise semtte inşa edilen atış poligonudur. Sultan'ın Almanya'yı diğer emperyalist devletlere nazaran daha zararsız görmesi iki ülkenin birçok alanda yakınlaşmasına neden olmuştur. ${ }^{37}$ Özellikle 1881 'den sonra gelen askeri danışma heyetlerinin ve silahların sayısı artmıştır. ${ }^{38}$ Buna mukabil, her nevi silahın tecrübe edilmesi ve bilhassa Almanya'dan gelen Mauser marka silahların denenmesi için Kâğıthane'de bir poligon kurulmuştur. ${ }^{39}$ Poligon'un yanında padişahın

\footnotetext{
32 BOA, Yıldız Teşrifat-ı Umumiye Dairesi (Y..PRK.TŞF.), 5/2, 21 Haziran 313/03 Temmuz 1897.

33 BOA, Yıldız Zabtiye Nezareti Maruzatı (Y..PRK.ZB.), 5/9, 11 RA 1307/05 Kasım 1889.

${ }^{34}$ BOA, Yıldız Name-i Hümayunlar (Y..PRK.NMH.), 5/1, 14 S 1309/19 Eylül 1891.

${ }^{35}$ BOA, Yıldız Başkitabet Dairesi Maruzatı (Y..PRK.BŞK), 44/4, 25 CA 1313/13 Kasım 1895.

${ }^{36}$ Mısır Hıdivi II. Abbas Hilmi Paşa'ya 3 adet tay gönderilmiştir. BOA, Y..PRK.BŞK., 41/86, 29 Z 1312/23 Haziran 1895.

37 "Sultan'ın Alman ittifakı ve Almanya'nın iktisadi etkisine karşı hudutsuz ve davetkâr bir eğilimi vardı." İlber Ortaylı, Osmanlı Imparatorluğu'nda Alman Nüfuzu, Kronik Kitap, İstanbul 2018. s. 72.

38 Feroze A.K. Yasamee, Abdülhamid'in Dış Politikası Düvel-i Muazzama Karşısında Osmanlı 1878-1888, (Çev. Yusuf Selman İnanç), Kronik Kitap, İstanbul 2018. s. 116-122. Ayrıca II. Abdülhamid döneminde Almanya'dan gelen silahlar hakkında ayrıntılı bilgi için bkz. Mehmet Beşirli, "II. Abdülhamid Döneminde Osmanlı Ordusunda Alman Silahları", Erciyes Üniversitesi Sosyal Bilimler Enstitüsü Dergisi, C. 1, S. 16, s. 121-139.

39 Poligonda Alman silahlarının yanı sıra Fransa, Belçika ve Avusturya'dan alınan silahlar da denenmiştir. BOA, Yıldız Yaveran ve Maiyyet-i Seniyye Erkan-ı Harbiye Dairesi (Y..PRK.MYD.), 11/69, 14 M 1310/08 Ağustos 1902.
}

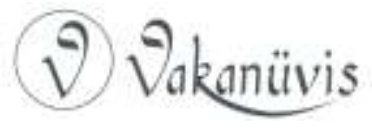


istirahat edip, talimleri seyredebileceği bir köşk de bulunmaktaydı. Poligon yeni silahların tecrübe ve talimi hususunda II. Abdülhamid devri boyunca hizmet vermiş ve dönem boyunca çok sayıda tadilat geçirmiştir. ${ }^{40}$

Sultan'ın Kâğıthane'ye olan ilgisinin bir başka nedeni ise Kâğıthane memba sularının lezzetidir. II. Abdülhamid'in içtiği sular konusunda oldukça hassas olduğu bilinmektedir. ${ }^{41}$ Hamidiye su şirketini kurmuş olması da suya olan ilgisinin bir tezahürüdür. ${ }^{42}$ Kendisinin de severek içtiği bu memba sularının kaynağını ise henüz şehzadeliğinde keşfettiğini şu şekilde ifade eder:

"Kâğıthane taraflarına çok defa ava gittiğim için oralarını pek iyi bilirim. Bir gün mevcut su sıkıntılarını def ederek halka iyi su içirmek için düşünürken o taraftaki su membaları gözümün önüne geldi. Tarifim veçhile su membalarını buldular. Hesap ettiler. Muhtelif memba suları toplanırsa bir yerde cem olursa bir hayli su hasıl oluyor. Ben de 20 bin lira sarf ettim. Demir borularla su getirdim. Şimdi halk o suyu içiyormuş." ${ }^{\prime \prime 3}$

İstanbul'un su ihtiyacının giderilmesine ayrı bir ihtimam gösteren Sultan, büyük masraflar yaparak ve Adliye Nazırı Abdurrahman Paşa'yı bizzat bu iş için görevlendirerek; Kâğıthane sularının, su sıkıntısı çeken

40 BOA, Y..A...RES., 93/81, 24 S 1316/14 Temmuz 1898; BOA, İrade Tophane-i Amire (i..TPH.), 12/12, 09 R 1321/05 Temmuz 1903; BOA, I...TPH., 14/69, 07 Z 1323/02 Şubat 1906.

41 II. Abdülhamid'in su konusundaki hassasiyeti hakkında ayrıntılı bilgi için bkz. Davut Hut, "Il. Abdülhamid'in İstanbul'un Su İhtiyacına Dair Politikası ve İçmeyi Tercih Ettiği Kaynak Suları", Sultan II. Abdülhamid Han ve Dönemi, (Ed. Fahrettin Gün, Halil Ibrahim Erbay), TBMM Basımevi, Ankara 2017, s. 470-491.

42 Hamidiye suları hakkında ayrıntılı bilgi için bkz. Kazım Çeçen, Hamidiye Suyu, DiA, C. XV, İstanbul 1997, s. 469-471; Kazım Çeçen, Taksim ve Hamidiye Suları, İstanbul Büyükşehir Belediyesi İski Yayınları, İstanbul 1992; Besim Ömer Paşa, "Kâğıthane Suları ve Hamidiye Çeşmeleri", Nevsâl-i Âfiyet, Sene III, Matbaa-ı Ahmed ihsan ve Şürekâsı, İstanbul 1320, s. 1-28; Zekeriya Kurşun - Sertaç Kayserilioğlu vd., Bâki Kente Âb-ı Bekâ: Hamidiye, İstanbul Büyükşehir Belediyesi Yayınları, İstanbul 2006, s. 51-71. ${ }^{43}$ Atıf Hüseyin Bey, Sultan Il. Abdülhamid'in Sürgün Günleri Hususi Doktoru Atıf Hüseyin Bey'in Hatıraları (1909-1918), (Haz. M. Metin Hülagü), Timaş Yayınları, İstanbul 2013, s. 434-435

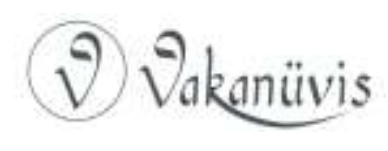


Beşiktaş ve Beyoğlu ${ }^{44}$ başta olmak üzere ikamet ettiği Yıldız Sarayı'na ${ }^{45}$ ve şehrin tamamına ulaştırılmasını sağlamıştır. ${ }^{46}$ Bunu yaparken de Kâğıthane'ye birçok yatırım yapmıştır. Öncelikle Kâğıthane'nin tatlı sularından halkın da yararlanması için mesire yerinin merkezine, masrafları Hazine-i Hassa bütçesinden karşılanmak üzere bir Hamidiye Çeşmesi inşa ettirmiştir. ${ }^{47}$ Sultan'ın imparatorluğun çeşitli yerlerinde inşa ettirdiği; çeşmeler, saat kuleleri, okullar ve camiler, Yıldız'a çekilen padişahın simgeler vasıtasıyla kendini halka hatırlatmasının bir tezahürüdür. ${ }^{48}$

Sultan, Hamidiye su yolu projesi kapsamında semte bir de Hamidiye Su Terazisi/Kulesi inşa ettirmiştir. ${ }^{49}$ Ayrıca bu memba sularından halkın yararlanabilmesi için dokuz bin lira masraf ile mermerden altı adet çeşme yapılmasını emretmiştir. ${ }^{50}$ Kâğıthane memba suları, kurulan makine ve tulumbalar ile yeryüzüne çıkarılırken ${ }^{51}$, künkler vasıtasıyla da şehir halkıyla buluşturulmuştur. ${ }^{52} 1903$ senesinde bir ara su kaynağına bilinmeyen bir nedenle acı su karışmışsa $\mathrm{da}^{53}$ devlet bu durumu kısa sürede çözmüştür. Zira birkaç yıl sonra yapılan tahkikler neticesinde memba yeniden saf sular sınıfında yer almıştır. ${ }^{54}$

${ }^{44}$ Kağıthane suları Taksimdeki depoya aktarılarak Beyoğlu ve Beşiktaş'a dağıtılmıştır. BOA, Yıldız Mütenevvi Maruzat (Y. MTV.), 9/23, 19 C 1299/08 Mayıs 1882.

45 BOA, ML.EEM., 216/84, 28 Teşrinievvel 1311/09 Kasım 1895.

46 Tahsin Paşa, Yıldız Hatıraları (Sultan II. Abdülhamit Han Devri Baş Mabeyni), (Haz. Ahmet Zeki İzgöer), ìz Yayıncılık, İstanbul 2018, s. 193, 261.

47 BOA, Yıldız Hazine-i Hassa (Y. PRK. HH.), 26/47, 26 L 1310/13 Mayıs 1893.

48 II. Abdülhamid döneminin simgeleri hakkında ayrıntılı bilgi için bkz. Selim Deringil, iktidarın Sembolleri ve Ideoloji (II. Abdülhamid Dönemi 1876-1909), (Çev. Gül Çağalı Güven), Doğan Kitap, İstanbul 2014.

${ }^{49}$ Şükrü Sönmezer, Soner Şahin, "Hamidiye Su Terazisi Tarihi, Mimarisi, İşlevi", Belleten, C. LXXVIII, S. 282, Ankara 2014, s. 603.

50 BOA, Yıldız Adliye ve Mezahib Nezareti Maruzatı (Y..PRK.AZN.), 23/21, 23 R 1320/30 Temmuz 1902.

${ }^{51}$ BOA, Y..MTV., 230/35, 07 Ş 1320/16 Mayıs 1902. Su makinası için getirilen alet edevat bir hırsızlık girişimine uğramıştır. BOA, ZB., 314/80, 27 RA 1325/10 Mayıs 1907.

52 BOA, Y..A...RES., 104/68, 17 \$̧ 1317/21 Aralık 1899.

53 “Kâğıthane menabi' sularına her nasılsa karışmış olan ecnebi ve tadı acı bir suyun diğer suların lezzet ve nefasetini ihlal etmekte olduğu anlaşıldığından mezkûr acı sular diğerlerinden ayrılarak onun yerine menabi' saire suları gibi leziz olmak üzere başka bir su bulunması..." BOA, Y..MTV., 248/54, 27 R 1321/23 Temmuz 1903.

${ }^{54}$ BOA, Y..MTV., 277/49, 13 C 1323/15 Ağustos 1905.

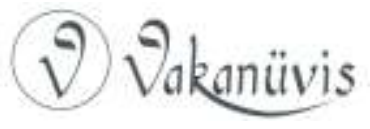


Padişah, Kâğıthane'de sayısız imar ve inşa çalışmasına imza atarken, semte yeni ve farklı yatırımlar yapılmasını da sağlamıştır. Poligon'un kurulması, su yollarının inşa edilmesi, çeşmeler yapılması, çok sayıda devlet binasının restorasyona tabi tutulması bunlara örnektir. Bu dönem başarılı yatırımların yanında birkaç başarısız yatırım girişimi de olmuştur. Semtte yeni girişimleri destekleyen Sultan, müteşebbis Balmumcu Rıza'nın bir kibrit fabrikası kurmak için arazi kiralamasına ve bu fabrika için Avrupa'dan getireceği aletlerin bir defaya mahsus olmak üzere gümrük resminden muaf tutulmasına müsaade etmiştir. ${ }^{55}$ Ancak bu girişim civardaki baruthaneler için sakıncalı olabileceği düşüncesiyle akim kalmıştır. ${ }^{56}$

\section{Kâğıthane Mesiresinden İnsan Manzaraları}

19. yüzyıla gelindiğinde İstanbul'da çok sayıda mesire yeri bulunmaktaydı. ${ }^{57}$ İstanbullular ilkbaharda Kâğıthane'ye giderken yazın daha ziyade Boğaziçi mesireleri olan; Göksu, Sultaniye, Beykoz, Büyükdere, Kalender, Bebek ve Şemsipaşa'yı tercih ederlerdi. ${ }^{58}$ Her ne kadar 19. yüzyılda bile Kâğıthane, mesireler arasında önemli bir yere sahipse de eski devirlerdeki ününü yitirmişti. Klasik dönemde oldukça önemli bir yeri olan Kâğıthane'nin bu konumu, II. Mahmud ve Abdülmecid gibi padişahların buraya gereken özeni göstermemesi

55 BOA, Şura-yı Devlet (ŞD.), 503/27, 09 ZA 1297/13 Ekim 1880.

56 BOA, Yıldız Şehremaneti Maruzatı (Y..PRK.ŞH..), 2/17, 25 Z 1301/15 Ekim 1884.

57 19. yüzyıl İstanbul' unda halkın gitmeyi tercih ettiği mesireler: "Çamlıklar, Çam Limanı, Kuşdili, Yoğurtçu, Fener Bahçesi, Kalamış, Haydarpaşa, Çiftehavuzlar, Mama, Kayışdağı, Alemdağı, Büyük Çamlıca Tepesi, Küçük Çamlıca Tepesi, Libade, Şemsipaşa, ibrahimağa, Susuz Bağı, Alay Köşkü, Duvardibi, Beylerbeyi Havuzbaşı Vaniköyü Top mahali, Kavacık, Göksu, Küçüksu, Hekimbaşı, Paşabahçesi, Sultaniye, Çubuklu, Kanlıca, Mihrabad, Göztepe, Beykoz, Karakulak Suyu Mevkii, Yuşa Tepesi, Tokad Kasrı, Anadolu feneri, Fırıldak Bahçesi, Hünkâr, Çırçır, Fındık, Kestane, Otuzbir Suları, Tarabya, Kalender, Koru, Fıstıklı, Baltalimanı, Rumelihisarı, Bebek, Beşiktaş, Ihlamur, Zincirlikuyu, Ayine Kavan Köşkü Yeri, Okmeydanı, Fulya, Eyüp Türbe Bahçesi, Bahariye Köşkü, Sögütlüçeşme, Sakızağacı, Siyavuşpaşa Çiftliği, Bayrampaşa, Florya ve Kâğıthane." Abdülaziz Bey, Osmanlı Adet, Merasim ve Tabirleri Toplum Hayatı, (Haz. Kazım Arısan, Duygu Arısan Günay), Tarih Vakfı Yurt Yayınları, İstanbul 1995, s. 297-298.

58 Salih Münir Paşa, Geçmiş Zamanlar (II. Abdülhamid Devri Osmanlı Diplomasisi, istanbul ve Paris Hatıraları), (Haz. Ali Birinci, Selma Günaydın), Türk Tarih Kurumu, Ankara 2015, s. 555.

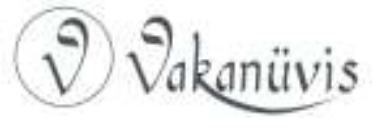


nedeniyle azalmıştır. Ancak ilerleyen yıllarda, bilhassa Sultan Abdülaziz'in bölgede yaptırdığı imar ve inşa çalışmaları sonucu 19. yüzyılın ikinci yarısından 20. yüzyılın başlarına kadar semt yeniden eğlence merkezi hüviyetine kavuşmuştur. ${ }^{59}$ Abdülaziz'in hariciye nazırlığını ve sadrazamlığını da yapan Keçecizade Fuat Paşa, Kâğıthane'nin çok değerli ve imara layık bir yer olduğundan bahsederek derenin iki yanına sahil rıhtımları inşa ettirmiştir. ${ }^{60} \mathrm{II}$. Abdülhamid döneminde ise restorasyon çalışmalarına önem verilerek; saraylar, kasırlar, köşkler, köprüler ve yollar restore edilmiş, inşa çalışmaları ve yeni yatırımlarla semt ihya edilmiştir.

Havaların ısınmaya başladığı Hıdırellez'den soğukların başladığı Kasım ayına kadar, Cuma ve Pazar günleri ile bazen de Çarşamba günleri Kâğıthane'de çok sayıda insan toplanırdı. Hafta içi nispeten sakin olan mesire yeri bu günlerde mahşer yeri gibi kalabalık olur, halk karadan ve dereden buraya akın ederdi. Her ağacın altı, her gölgelik alan insanla dolar, mesire alanına girip çıkmak imkânsız derecesinde zorlaşırdı. ${ }^{61}$ Tüm bu kalabalığa rağmen burası, İstanbul'da bir tatil gününü eğlenceli geçirmek için tercih edilebilecek en güzel yerlerden biriydi. Akşam vakti ağaçların altında yeni tomurcuklanan çiçeklerin arasında yürümek insana yaşadığı dünyadan koparak, başka bir dünyadaymış hissi verirdi. $^{62}$

Bahar aylarında akın akın Kâğıthane'ye gelen halk için birçok ulaşım seçeneği mevcuttu. Klasik dönemlerde sandal, kayık, at arabası veya yaya olarak mesireye ulaşılırken, II. Abdülhamid döneminde vapur yeni bir alternatif oluşturmuştur. Ancak sandal ve kayıkların yoğunluğu nedeniyle vapurlar Kâğıthane'ye yanaşamadığından yolcuları genellikle Karaağaç'ta indirmiştir. Sandal yoğunluğunun yanı sıra Kâğıthane deresinin taşıdığı alüvyonların havzayı doldurması nedeniyle Haliç

\footnotetext{
59 Semavi Eyice, "İstanbul Halkının ve Padişahlarının Ünlü Mesiresi: Kâğıthane”, İstanbul Armağanı - 3 Günlük Hayatın Renkleri, (Haz. Mustafa Armağan), İstanbul Büyükşehir Belediyesi Kültür İşleri Daire Başkanlığı Yayınları, İstanbul 1997, s. 89

${ }^{60}$ Balıkhane Nazırı Ali Rıza Bey, Bir Zamanlar Istanbul, (Haz. Niyazi Ahmet Banoğlu), Tercüman 1001 Temel Eser, İstanbul 1922, s. 201.

61 Ercüment Ekrem, Münif Fehim, Dünden Hatıralar, "Kâğıthane", Yedigün Neşriyat, İstanbul 1945.

62 Friedrich Schrader, Istanbul 100 Yıl Öncesine Bir Bakış, s. 174.
}

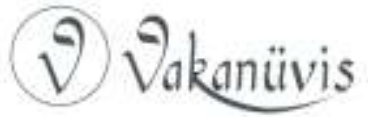


vapurlarının Kâğıthane'ye yanaşması uzun süre sorun olmuştur. ${ }^{63} \mathrm{Bu}$ yüzden insanların birçoğu Eyüp'e giderek oradan kayıkla geçmeyi tercih etmiştir. ${ }^{64}$ Ancak kayıkla yolculuk sırasında sık sık kazalar olmuştur. Kaza geçiren yolcuları çevrede kol gezen askerler kurtarmıştır. ${ }^{65}$ Deniz yoluyla ulaşım daha çok tercih edilse de kara yolu ile ulaşımı tercih edenler de az değildi. Çevre semtlerden fayton ve arabalarla semte gelenlerin sayısı bir hayli fazlaydı. Faytonların yaptığı toz ise yaya olarak gidenleri zor durumda bırakmıştır. ${ }^{66}$

Kâğıthane, Müslüman ahali kadar gayrimüslim ahalinin de çok rağbet ettiği mesire yerleri arasındadır. Hatta zaman zaman Kâğıthane'deki Gayrimüslim vatandaşların ve Frenklerin sayısının Müslümanlardan fazla olduğu bile söylenmekteydi. Kâğıthane'de Rumların yoğun olduğu günlerden birisi de Rum Yortusu olarak bilinen Aya Kalliopi Yortusu'nun kutlandığı 8 Haziran tarihidir. O tarihte Kâğıthane deresi öyle yoğun olurdu ki kayıklar sıra ile kürek çekmek zorunda kalırdı. ${ }^{67}$ Bilhassa Cuma günleri hareketli olan semt, köpük köpük dökülen sular, pırıl pırıl parlayan çiçekler ve yemyeşil geniş çayırları ile Müslüman/gayrimüslim toplumun her kesimini cezbetmiştir. ${ }^{68}$

Kâğıthane mesiresinin önemli unsurlarından biri de Çingenelerdi. Çeşte ve küdüm denilen sazları boyunlarına asarak mesire yerine gelen Balat çingeneleri bir yandan çalar bir yandan oynarlardı. ${ }^{69} \mathrm{Bu}$ çingeneler çalgıcılık işleriyle meşgul oldukları gibi falcılık da yaparlardı. ${ }^{70}$ Bilhassa kadın çingeneler İstanbul'da yaşayan diğer kadınlara nazaran oldukça serbest yaşarlar, diledikleri gibi rahat giyinip sokaklarda kol gezerlerdi.

63 Ali Akyıldız, Osmanlıda Ulaşımın Modernleşmesi, Timaş Yayınları, İstanbul 2019, s. 102-104.

${ }^{64}$ Sadri Sema, Eski istanbul Hatıraları, (Haz. Ali Şükrü Çoruk), Kitabevi, İstanbul 2002, s. 129.

65 BOA, Zabtiye (ZB.), 366/26 14 Haziran 1323/ 27 Haziran 1907.

${ }^{66}$ Sermet Muhtar Alus, Masal Olanlar, s. 262.

${ }^{67}$ Lady Hornby, Kırım Savaşı Sırasında İstanbul, (Çev. Kerem Işık), Kitap Yayınevi, İstanbul 2007, s. 323.

68 La Baronne Durand De Fontmagne - Kırım Harbi Sonrasında istanbul, (Çev. Gülçiçek Soytürk), Tercüman, İstanbul 1977, s. 225.

69 İsmail Altınöz, Osmanlı Toplumunda Çingeneler, Türk Tarih Kurumu, Ankara 2013, s. 286.

${ }^{70}$ Lady Hornby, Kırım Savaşı Sırasında İstanbul, s. 326.

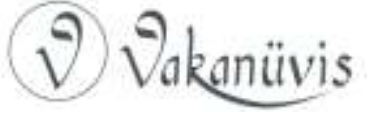


Çingene kadınları genellikle kırmızı mintan, sarı renkli bir şalvar, ayaklarına sarı pabuç ve sırtlarına mavi boyalı cübbe giyerlerdi. ${ }^{71}$

Tatil günlerinde Sâdâbâd deresi kayık ve sandallardan geçilmez, her ağaç altı her köşe başı piknik yapanlarla dolup taşar; çingeneler dans edip fal bakar, her köşeden enstrüman sesleri ve müzik nameleri yükselir, yemekler yenir, içecekler içilir, zevk ve sefa içinde günler geçirilirdi. Bulgarlar gayda, Araplar tanbur çalarken; hokkabazlar gösteri yapar, ayı ve maymun oynatılırdı. ${ }^{72}$ Nedim'in şiirlerinde insanı büyüleyen o meşhur Kâğıthane sihrinin kalıntıları, 19. yüzyılda bile hala etkisini korumaktaydı. ${ }^{73}$

Kâğıthane mesiresi bir eğlence merkezi olmasının yanı sıra modanın da merkezi konumundadır. Buraya gelen kadın ve erkekler, en güzel kıyafetlerini giyerken adeta dönemin modasını da belirlerlerdi. 19. yüzyılın ortalarında durumu iyi olan kadınlar; beyaz yaşmak ve gül pembe, mavi, kiraz rengi, elma yeşili veya saman rengi feraceleri ile gezerlerdi. Durumu daha kötü olan kadınlar ise kahverengi veya koyu yeşil ferace giyerlerdi. ${ }^{74}$ Ayrıca buraya gelen kadınlar, ağız ve burunlarını kapatan eski usul peçelerin yerine çenenin altında toplanan ince beyaz bir tül kullanırlardı. ${ }^{75}$ Erkekler ise; kafalarında fes, gözlerinde gözlük, ellerinde baston, gömlek kolları dışarda, pantolon paçaları geniş olacak şekilde giyinirlerdi. ${ }^{76}$ Kadın-erkek fark etmeksizin elbiseler ütülenir, eskiyse yenileri alınırdı. Erkekler tıraş olup yüzlerine losyon, üstlerine lavanta kokuları sürerlerdi. ${ }^{77}$ Ayrıca derenin etrafındaki sazlardan sivri külahlar yapan gençler bunları kafalarına takarak gezerlerdi. ${ }^{78}$

Mesireye gelen insanlar kadar, onları mesireye getiren arabaların da estetik arayışında olması hayli ilginçtir. Öküz arabaları rengarenk yaldızlı

\footnotetext{
${ }^{71}$ Abdülaziz Bey, Osmanlı Adet, Merasim ve Tabirleri Toplum Hayatı, (Haz. Kazım Arısan, Duygu Arısan Günay), Tarih Vakfı Yurt Yayınları, İstanbul 1995, s. 329.

72 Balıkhane Nazırı Ali Rıza Bey, Bir Zamanlar istanbul, s. 207.

${ }^{73}$ Sadri Sema, Eski istanbul Hatıraları, s. 128.

${ }^{74}$ Lady Hornby, Kırım Savaşı Sırasında İstanbul, s. 323.

75 Francis Marion-Crawford, 1890'larda istanbul, (Çev. Şeniz Türkömer), Türkiye İş Bankası Kültür Yayınları, İstanbul 2018, s. 17.

76 Basiretçi Ali Efendi, İstanbul Şehir Mektupları, (Haz. Nuri Sağlam), Erdem Yayınları, İstanbul 2017, s. 65.

77 A. Süheyl Ünver, "Her Devirde Kağıthane”, Varlık Dergisi, S. 10, Ankara 1969, s. 458.

78 Salih Münir Paşa, Geçmiş Zamanlar, s. 556.
}

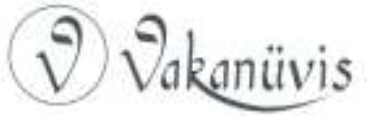


ve kabartmalı şekilde süslenirken, arabacılar da başlarına mavi püsküllü kırmızı fes, ayaklarına mavi dizlik, bellerine ise kırmızı kuşak takmak suretiyle ${ }^{79}$ mesirenin süslü insanlarına en az o kadar renkli bir hizmet vermekteydiler. Hali-i hazırda her şey bu kadar renkli iken bu renk cümbüşüne katkı sağlayan bir diğer grup da destancılar olmuştur. Koltuklarının altında renkli kağıtlarla dolaşan bu destancılar, mesire günleri yüksek sesle bağırarak sahip oldukları destanların reklamını yapar, beğendirdikleri destanları satarlardı. ${ }^{80} \mathrm{Bu}$ destanların arasında zaman zaman zararlı bulunanlar da olmuştur. Devlet zararlı yayınların önüne geçmek için Matbuat Nizamnamesi 'ne dayanarak bu yayınları toplatmıştır. Böylesi bir örnekte Kâğıthane mesiresinde Balatlı Lütfi Ağa'nın satışını yaptığı Yorgancı Sadık Destanı'na el konmuştur. ${ }^{81}$

Kâğıthane'de, bugün de olduğu gibi piknik ve mesire yerlerinde insanların yiyecek ihtiyaçlarını karşılayan birçok seyyar satıcı bulunmaktaydı. Mesireye gelenlerin çoğu evden bir şeyler getirmek suretiyle, bir ağaç gölgesine oturarak akşama kadar yiyip içerlerdi. Sefertaslarına doldurulan söğüş, dolma ve helvalar ile Kâğıthane yoğurdu yenirdi. ${ }^{82}$ Her ne kadar evden leziz yemekler getirilmiş olsa da yine de dışarıda satılanların insanları cezbetmesi sonucu, seyyar satıcılardan da bir şeyler alınırdı. Bu satıcılar; macun, yoğurt, simit, bademli kurabiye, şerbet, helva, şeker, lokum, mısır, portakal, turşu, gazoz, limonata, börek, muhallebi, yemiş ve kebap satarlardı. ${ }^{83}$

Başta sıbyan olmak üzere farklı seviyelerde mekteplerin havalar güzelleştiğinde çevrelerindeki mesire yerlerine geziler düzenledikleri bilinmektedir. Kâğıthane de çevre semtlerdeki okullar için bir gezi yeri olmuştur. Gezilerin yanı sıra burada talim, yürüyüş ve ziyafetler de düzenlenmiştir. Mektep talebelerinin geziye götürüldüğü yerler

\footnotetext{
79 Abdülaziz Bey, Osmanlı Adet, Merasim ve Tabirleri Toplum Hayatı, s. 293.

80 Bu destanlardan bazıları şunlardır: "Kocasını Dolaba Koyan Çilli Fatma, Kömürlükte Yakalanan Zampara, Karısını Atlatan Hovarda, Kanlı Fuad, Tasını Tarağını Satıp Kâğıthane'ye Giden Guguk Zeynep." Sadri Sema, Eski Istanbul Hatıraları, s. 272.

81 BOA, Maarif Nezareti Mektubi Kalemi (MF. MKT.) 397/57 09 M 1316/30 Mayıs 1898.

82 Salih Münir Paşa, Geçmiş Zamanlar, s. 555.

83 Lady Hornby, Kırım Savaşı Sırasında Istanbul, s. 325; Abdülaziz Bey, Osmanlı Adet, Merasim ve Tabirleri Toplum Hayatı, s. 296; Sadri Sema, Eski Istanbul Hatıraları, s. 342. Buralarda satılan kebapları eleştiren Basiretçi Ali, şişi on paraya satılan kebapların basura neden olduğundan bahseder. Basiretçi Ali, Istanbul Şehir Mektupları, s. 286.
}

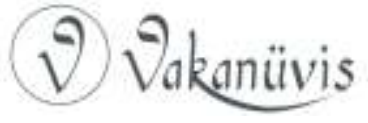


arasında; Veli Efendi Çayırı, Beykoz Çayırı, Çoban Çeşmesi, Silahtarağa Çeşmesi, Göksu Çayırı, Balta Limanı Çayırı ve elbette Kâğıthane mesiresi vardır. ${ }^{84}$ Sultan Abdülmecid devrinde Mekteb-i Maarif-i Adliye öğrencilerinin gezi amacıyla Kâğıthane'ye geldikleri arşiv belgelerine yansımıştır. ${ }^{85}$

Mesire ile ilgili yazanların birçoğu olumlu noktalara değinip hatırlarında kalan güzellikleri yansıtmış olsalar bile bu kadar insanın bir arada olduğu bir yerde olumsuz durumlar da yaşanmıştır. Öncelikle, mesirenin tüm güzelliğine rağmen kalabalıktan ve arabaların neden olduğu tozdan dolayı rahatsız edici düzeyde kirlilik oluşturduğu buraya gelen hemen her yazarın/seyyahın ortak fikridir. Ayrıca mesireye gelen kadınlara sarkıntılık etmek, mendilini ve şemsiyesini kapmak gibi rahatsız edici durumlar da sıklıkla görülmüştür. ${ }^{86}$ Buraya gelen bazı erkekler kadınlara el ve dil ile sarkıntılık eder, bıyık burar, yüksek tabakadan bir kadınla tanışmak hülyasında olanlar konak arabalarının etrafında dolanırdı. Bu durumdan rahatsız olan kadınlar ise şemsiyeleri ile yüzlerini kapatırlardı. ${ }^{87}$ Kalabalıkta görülen bu ve benzeri daha birçok olumsuz duruma engel olmak amacıyla devlet mesire mevsimi başlamadan evvel ilgili birimlere uyarı mahiyetinde yazılar göndermiştir. ${ }^{88}$ Bilhassa baharın başlangıcı sayılan Hıdırellez gününde alınan tedbirler had safhaya çıkarılmıştır. ${ }^{89}$

Tüm uyarılara ve alınan sıkı güvenlik önemlerine rağmen mesire, bazen istenmeyen olaylara sahne olmuştur. Mesire yerine piknik için gelen günübirlikçilerin, gün boyu su ihtiyaçlarını karşıladıkları çeşmelerde yoğunluk yaşandığından, kimi zaman bu çeşmelerin başında

\footnotetext{
${ }^{84}$ Abdülaziz Bey, Osmanlı Adet, Merasim ve Tabirleri Toplum Hayatı, s. 65.

85 BOA, İrade Dâhiliye (i. DH.), 17/785 10 CA 1256/ 10 Temmuz 1840.

86 Basiretçi Ali Efendi, İstanbul Şehir Mektupları, s. 27, 470.

87 Balıkhane Nazırı Ali Rıza Bey, Bir Zamanlar İstanbul, s. 205-206.

88 "Ve Kâğıthane için de cümleye mahsus olan jandarma kullarının dahi yevm-i mezkurda ale's-sabah tamamen orada bulundurulması hususuna himem." BOA, ZB., 383/32, 17 Nisan 324/30 Nisan 1908.

89 “Önümüzdeki Salı günü Rûz-ı Hızır olmak hasebiyle diğer mesireler misüllü Kâğıthane kalabalık olacağı ... Kâğıthane mesiresinde gezdirilmesi lazım gelen altışar neferden ibaret iki süvari nizamiye kolunun da bir süvari polis refakatiyle dolaşmak üzere ..." BOA, Y..PRK. ZB., 32/45, 21 Nisan 318/04 Mayıs 1902.
}

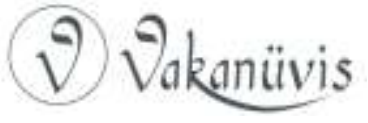


kavga çıkmıştır. ${ }^{90}$ Mesire yerinde kadınların giyim kuşam ve davranışları hususunda devletin çok hassas olduğu bilinmektedir. Nitekim 1891 baharında Kâğıthane'ye yaptığı bir gezinti sırasında Sultan, bazı kadınların açık giyindiklerine bizzat şahit olarak bu hususta gerekenin yapılmasını istemiştir. ${ }^{91}$ Bundan başka mesirede eğlenceyi fazla kaçırarak kendisini Kâğıthane deresine atanlar yahut istemsiz olarak düşenler de olmuştur. Böylesi bir olayda; Nisan ayının ortasında Cuma günü mesireye gelen Bosnalı Fettah bin Durmuş isimli şahıs, sarhoş bir halde kendisini dereye atmıştır. Bu esnada mesirede gezintide bulunan memurlar; Mehmed Nazif, Ahmed, Mehmed, Recep ve Seyfi Efendilerin bir sandal ile yetişerek boğulmak üzere olan şahsı kurtarmış ve başarılarından dolayı madalya ile taltif edilmişlerdir. ${ }^{92}$ Yine bir Cuma günü eğlencelere katılan Yıldız kasrı kaymakamlarından Cemal Bey ve ailesi kara yolu ile dönerken boğulma tehlikesi geçirmişlerdir. Bu ilginç olayda arabacının bir aralık su almak için dereye yönelmesini fırsat bilen beygirlerin su içmek amacıyla dereye doğru hareket etmesiyle arabadakiler ölümle burun buruna gelmiş fakat son anda kurtarılmışlardır. ${ }^{93}$ Mesirede yaşanan başka bir vaka ise ölümle

\footnotetext{
90 BOA, Yıldız Arzuhal Jurnal (Y..PRK..AZJ.), 47/49, 29 Z 1320/29 Mart 1903.

91 "Geçenlerde Kâğıthane'ye teşrif-i meali-redif-i hazreti padişahi ... ba'zı kadınların gayri mestûre denilecek sûrette yüzlerine anca bir tül örtmüş olduklarına veli-i ni'met-i bi minnetimiz efendi hazretleri şahit buyurulmuş oldukları ve bu babda..." BOA, DH. MKT., 1825/19, 23 Ş 1308/03 Nisan 1891.

92 “Nisan'ın on beşinci Cuma günü Kâğıthane mesiresine giderek kendisini denize atmış olan kırk çeşme medresesinde mûkim Bosnalı Fettah bin Durmuş me'muren mahall-i mezkûrede bulunan nüfus idaresine me'mur polis ser komiseri Mehmed Nazif ve devâir birinci polis ihtiyat bölüğü efradından Bâb-ı Âli'de müstahdem Çavuş Ahmed ve orman ve mâ'den nezaretinde müstahdem Mehmed ve Defter-i Hâkâni'de müstahdem Receb ve telgrafhane muhabere me'murlarından Seyfi Efendiler tarafından sandal ile üzerine giderek tahlisiye edilmiş olduğuna binaen muma ileyhiden ser komiser Mehmed Nazif Efendi'nin hâsıl olacağı tahlisiye madalyası kurdelesinin beyaz ve Çavuş Ahmed Efendi'nin tahlisiye madalyası kurdelesinin kırmızı tebdili ve Mehmed ve Receb ve Seyfi efendilerin birer kıt'a tahlisiye madalyası ile taltif ve tesrirleri menut-ı vilayet-i aliyye-i dâverâneleri bulunmuş olmağla ol babda emru ferman hazreti men lehü'l-emrindir." BOA, DH. MKT., 954/61, 03 RA 1323/08 Mayıs 1905.

93 "Yıldız Sarayı şevket-ihtivası civarında arâm-saz asâkir-i şahane zabitanından Kaimmakam Cemal Bey'in haremiyle hemşiresi ve iki mahdumu Varna muhacirlerinden Mahmud nâm kimesnenin arabasıyla dünkü Cuma günü Kâğıthane'ye giderek esna-yı avdetlerinde merkum arabacının Silahdarağa civarında beygirlere su vermek üzere iken hayvanların denize uğrayıp gark olmak derecesine geldiği görülerek derhal yetişilerek
}

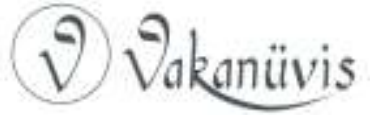


sonuçlanmıştır. Mesirenin kalabalık olduğu bir Temmuz akşamı, 25'li yaşlarda bir gayrimüslim mesire yerinde revolver (toplu tabanca) ile intihar etmiştir. ${ }^{94}$

Kâğıthane mesiresine gelişler ve mesirede yaşanan eğlenceler kadar, dönüşler de hayli renkli görüntülere sahne olurdu. Rengarenk süslenen kayıklar taşıdıkları süslü insanlarla adeta bir renk cümbüşü oluştururdu. Dönüş esnasında kayıklarda müzik yapanlar, birbiriyle yarışanlar, kayıktan kayığa geçenler, dere kenarında onları izleyen insanlar ile karayoluyla dönen at arabalı insanlar ve yayalar büyük bir cümbüşe neden olurdu. Kâğıthane mesiresine gidemeyen civar semtlerin insanları için bu törensel geçidi izlemek, en az Kâğıthane mesiresi kadar eğlenceli olurdu. ${ }^{95}$

\section{Sonuç}

Kâğıthane mesiresi 15. yüzyıldan itibaren Osmanlı Devleti'nin en önemli mesire ve eğlence merkezi olarak öne çıkmaktadır. III. Ahmed ile özdeşleşen Lale Devri'nin yaşandığı mekanlar arasında en önemlisidir. Bir devrin eğlence merkezi olan, birçok devirde sayısız insana ev sahipliği yapan bu güzide semt, devletin son yıllarında eski ihtişamını kaybetmiştir. Bunda farklı mesirelerin öne çıkması, farklı eğlence anlayışlarının gelişmesi, hâlihazırda devletin içinde bulunduğu sıkıntılı durum ve akabinde onlarca yıl süren savaşlar etkili olmuştur. Ancak yine de semt, 20. yüzyılın başlarına kadar her kesimden insanın; Müslüman, gayrimüslim ve bilhassa yurtdışından gelen ziyaretçilerin akınına uğramaya devam etmiştir. Kâğıthane mesiresi hakkında yazan yazarların hemen hepsinin ortak görüşü buranın diğer tüm mesire yerlerini gölgede bırakan bir güzelliğe sahip olduğudur. Bu nedenle; şahane

araba derununda bulunanların kurtarıldığı ve çocukların bera-yı tedavi iplikhane hastanesine ve mezbûrelerin de kendi hanelerine götürüldügüne dair ikinci daire-i belediye müfettişliğinden vârid olan jurnal aynen ve leffen arz ve takdim kılınmış olmağla ol babda ver her halde emr-u ferman hazret-i veliyyül emrindir." BOA, Y..PRK. ASK., 20/18, 18 Z 1300/20 Ekim 1883.

94 "Kâğıthane mesiresinde Rum veyahut Frenk yirmi beş otuz yaşlarında bir şahsın bugün saat akşam raddelerinde revolver ile kendi kendisini itlaf eylediği haber alınması üzerine bizzat icra-yı tahkikat olunarak fi'l vaki ol vecihle intihar eylediği tesbit edilmiş..." BOA, Y..PRK.ZB.., 19/53, 06 S 1315/07 Temmuz 1897.

${ }^{95}$ Balıkhane Nazırı Ali Rıza Bey, Bir Zamanlar ístanbul, s. 208-209.

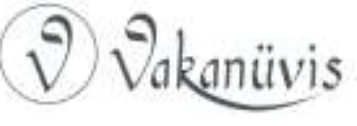


Kâğıthane, ${ }^{96}$ mesirelerin en âlâss ${ }^{97}$, mesire yerlerinin en latif ve hoş olanı, ${ }^{98}$ mesire-i rûh-efzâa ${ }^{99}$ gibi ifadeler kullanmışlardır.

Sultan II. Abdülhamid döneminde Kâğıthane'de hayli ilginç insan manzaraları karşımıza çıkmaktadır. Bunun temel nedeni; her milletten ve toplumun tüm tabakalarından insanların burada kolektif bir eğlencede buluşabilmiş olmasıdır. Kâğıthane halkın; sultanları, saray erkanını, paşaları, köşk ve konaklarda yaşayan zenginleri, bunların aileleri ile maiyetlerinin parıltılı yaşamlarını yakından görebildikleri yegâne yer olmuştur. Saray erkanı ve paşalar gibi toplumun en üst kademesinin yanı sıra toplumun alt kademesinden sayılabilecek sokak satıcıları, kayıkçılar, efsuncular, falcılar, destancılar gibi farklı meslek grupları; Rumlar, Ermeniler, Yahudiler gibi farklı milletler ve Çingeneler ile yurtdışından gelen sayısız insan burada bir araya gelmiştir. Bu yönüyle Kâğıthane; Osmanlı İmparatorluğu'nun etnik mozaik yapısını en iyi yansıtan yerler arasındadır.

Sultan II. Abdülhamid'in semte yaklaşımı ise oldukça derin ve evveliyatı olan bir meseledir. II. Abdülhamid henüz şehzade iken burada uzun zaman geçirmiş ve burayı hem sevmiş hem de çok iyi tanımıştır. Kâğıthane su membalarını bizzat kendisi bularak Hamidiye sularının kaynağı olarak halkın kullanımına sunmuştur. Mesirenin ve su kaynaklarının güvenliği hususunda çok hassas davranmıştır. Bunun yanı sıra semte sayısız yatırım yapmış, imar ve restorasyon faaliyetlerinde bulunmuştur. II. Abdülhamid devrinde son parlak günlerini yaşayan mesire, onun sayesinde ömrünü uzatabilmiş ve uzun yıllar gündemde kalabilmiştir. Bu yönüyle Sultan, semtin yüzyıllardır süregelen ve sönmeye yüz tutmuş parlaklığının muhafazasında önemli bir rol oynamıştır. Sonuç olarak, Julia Pardoe'nün dediği gibi: "yeryüzünde bir yaz gününü geçirmek için Kâğıthane'den daha iyi, daha hoş, daha parıltılı bir yer yoktur." ${ }^{\prime 100}$

\footnotetext{
${ }^{96}$ Karanov, Maçarov, Naçov, Bulgar Gözüyle İstanbul, (Haz. Hüseyin Mevsim), Türk Tarih Kurumu, Ankara 2011, s. 24.

97 Basiretçi Ali Efendi, İstanbul Şehir Mektupları, s. 27.

98 Abdülaziz Bey, Osmanlı Adet, Merasim ve Tabirleri Toplum Hayatı, s. 293.

${ }_{99}$ Basiretçi Ali Efendi, istanbul Şehir Mektupları, s. 266.

100 Julia Pardoe, Sultanlar Şehri İstanbul, s. 231.
}

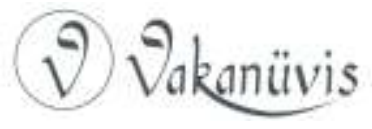




\section{Kaynaklar}

\section{Arşiv Kaynakları}

Türkiye Cumhuriyeti Cumhurbaşkanlığı Osmanlı Devlet Arşivi (BOA),

Dâhiliye Mektubî (DH. MKT.), nr. 1825/19; nr. 954/61; nr. 1824/65; nr. 1493/103; nr. 1503/28

İrade Dâhiliye (i. DH.), nr. 17/785

İrade Evkaf (i...EV...), nr. 37/44

İrade Şura-yı Devlet (i...ŞD..), nr. 54/3046

İrade Tophane-i Amire (i...TPH.), nr. 12/12; nr. 14/69

Maliye Nezareti Emlak-i Emiriyye Müdüriyeti (ML.EEM.), nr. 317/27; nr. 320/17; nr. 216/84

Maarif Nezareti Mektubî Kalemi (MF. MKT.) nr. 397/57

Şura-yı Devlet (ŞD.), nr. 503/27

Yıldız Adliye ve Mezahib Nezareti Maruzatı (Y..PRK.AZN.), nr. 23/21

Yıldız Arzuhal Jurnal (Y..PRK..AZJ.), nr. 47/49

Yıldız Askeri Maruzat (Y.. PRK. ASK.), nr. 98/45; nr. 174/97; nr. 176/5; nr. $20 / 18$

Yıldız Başkitabet Dairesi Maruzatı (Y..PRK.BŞK), nr. 44/4; nr. 41/86

Yıldız Hazine-i Hassa (Y. PRK. HH.), nr. 26/41

Yıldız Hazine-i Hassa (Y.PRK.HH..), nr. 6/29

Yıldız Mabeyn Erkanı ve Saray Görevlileri Evrakı (Y..PRK..SGE.),nr. 6/32

Yıldız Müteferrik (Y..PRK.M...), nr. 2/72

Yıldız Mütenevvi Maruzat (Y..MTV.), nr. 230/35; nr. 248/54; nr. 277/49; nr. 9/23.

Yıldız Name-i Hümayunlar (Y..PRK.NMH.), nr. 5/1

Yıldız Resmi Maruzat (Y..A..RES.), nr. 73/43; nr. 93/81; nr. 104/68

Yıldız Şehremaneti Maruzatı (Y..PRK.ŞH..), nr. 2/17

Yıldız Teşrifat-ı Umumiye Dairesi (Y..PRK.TŞF.), nr. 5/2

Yıldız Yaveran ve Maiyyet-i Seniyye Erkan-ı Harbiye Dairesi (Y..PRK.MYD.), nr. $11 / 69$

Yıldız Zabtiye Nezareti Maruzatı (Y..PRK. ZB.), nr. 32/45; nr. 19/53; nr. 5/9

Zabtiye (ZB.), nr. 366/26; nr. 383/32; nr. 314/80

\section{Araştırma ve İnceleme Eserleri}

Abdülaziz Bey, Osmanlı Adet, Merasim ve Tabirleri Toplum Hayatı, (Haz. Kazım Arısan, Duygu Arısan Günay), Tarih Vakfı Yurt Yayınları, İstanbul 1995.

Ahmet Mithat Efendi - Felâtun Bey ve Râkım Efendi, (Haz. Emrah Balcı), Türkiye İş Bankası Kültür Yayınları, İstanbul 2019.

AKYILDIZ, Ali, Osmanlıda Ulaşımın Modernleşmesi, Timaş Yayınları, İstanbul 2019.

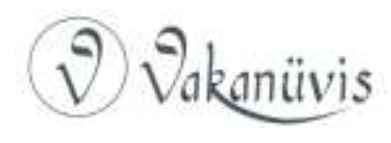


ALTINAY, Ahmet Refik- Lale Devri (1718-1730), Tarih Vakfı Yurt Yayınları, İstanbul 2011.

, Ahmet Refik, Kafes ve Ferace Devrinde Istanbul, (Haz. Tahir Yücel), Kitabevi, İstanbul 1998.

ALTINÖZ, İsmail, Osmanlı Toplumunda Çingeneler, Türk Tarih Kurumu, Ankara 2013.

ALUS, Sermet Muhtar, Masal Olanlar, (Haz. Nuri Akbayar), iletişim Yayınları, İstanbul 1997.

ATIF, Hüseyin Bey, Sultan II. Abdülhamid'in Sürgün Günleri Hususi Doktoru Atıf Hüseyin Bey'in Hatıraları (1909-1918), (Haz. M. Metin Hülagü), Timaş Yayınları, İstanbul 2013.

Balıkhane Nazırı Ali Rıza Bey, Bir Zamanlar Istanbul, (Haz. Niyazi Ahmet Banoğlu), Tercüman 1001 Temel Eser, İstanbul 1922.

BASIRETÇi, Ali Efendi, İstanbul Şehir Mektupları, (Haz. Nuri Sağlam), Erdem Yayınları, İstanbul 2017.

Besim Ömer Paşa, "Kâğıthane Suları ve Hamidiye Çeşmeleri", Nevsâl-i Âfiyet, Sene III, Matbaa-ı Ahmed İhsan ve Şurekası, İstanbul 1320, s. 1-28.

BEŞiRLi, Mehmet, "II. Abdülhamid Döneminde Osmanlı Ordusunda Alman Silahları", Erciyes Üniversitesi Sosyal Bilimler Enstitüsü Dergisi, C. 1, S. 16, s. 121-139.

BiLGicioĞLU, Banu, "Sâdâbâd", Türkiye Diyanet Vakfı İslam Ansiklopedisi (DiA), c. 35, İstanbul 2008, s. 379-381.

BYZANTiOS, Dionysios, Deniz Yoluyla Boğaz, (Çev. Erendiz Özbayoğlu), TB Yayıncılık, İstanbul 2009.

ÇEÇEN, Kazım, Hamidiye Suyu, DiA, C. XV, İstanbul 1997, s. 469-471.

------, Kazım, Taksim ve Hamidiye Suları, İstanbul Büyükşehir Belediyesi İski Yayınları, İstanbul 1992.

DERINGIL, Selim, İktidarın Sembolleri ve Ideoloji (II. Abdülhamid Dönemi 1876-1909), (Çev. Gül Çağalı Güven), Doğan Kitap, İstanbul 2014.

EKREM, Ercüment, FEHIM, Münif, Dünden Hatıralar, "Kağıthane", Yedigün Neşriyat, İstanbul 1945.

ENGiN, Vahdettin, Bir Devrin Son Sultanı II. Abdülhamid, Yeditepe Yayınevi, İstanbul 2018.

EYICE, Semavi, "İstanbul Halkının ve Padişahlarının Ünlü Mesiresi: Kâğıthane”, İstanbul Armağanı - 3 Günlük Hayatın Renkleri, (Haz. Mustafa Armağan), İstanbul Büyükşehir Belediyesi Kültür İşleri Daire Başkanlığı Yayınları, İstanbul 1997.

FOTMAGNE, La Baronne Durand De - Kırım Harbi Sonrasında Istanbul, (Çev. Gülçiçek Soytürk), Tercüman, İstanbul 1977.

GEORGEON, François, Sultan Abdülhamid, (Çev. Ali Berktay), Iletişim Yayınları, İstanbul 2018.

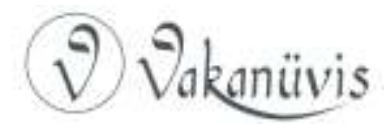


HORNBY, Lady, Kırım Savaşı Sırasında Istanbul, (Çev. Kerem Işık), Kitap Yayınevi, İstanbul 2007.

HUT, Davut, "II. Abdülhamid'in İstanbul'un Su İhtiyacına Dair Politikası ve İçmeyi Tercih Ettiği Kaynak Suları", Sultan II. Abdülhamid Han ve Dönemi, (Ed. Fahrettin Gün, Halil İbrahim Erbay), TBMM Basımevi, Ankara 2017, s. 470-491.

-----, Davut, “Beykoz'un Meşhur Kaynak Suları: 19 ve 20. Yüzyıllarda Karakulak, Çubuklu, Göztepe ve Sırmakeş Suları Üzerine Bir Değerlendirme", Beykoz 2019 Sempozyumu Tebliğler Kitabı, Beykoz Belediyesi Kültür Yayınları: 35, İstanbul 2020, s. 307-320.

IRMAK, Hüseyin, IIlk Çağdan Günümüze Kağıthane, Kağıthane Belediyesi Kültür Yayınları, C. I, İstanbul 2018.

inciCiYAN, P. G., XVIII. Asırda istanbul, (Çev. Hrand D. Andreasyan), İstanbul Enstitüsü Yayınları, İstanbul 1956.

KAHRAMAN, Seyit Ali, DAĞLI, Yücel, Günümüz Türkçesiyle Evliya Çelebi Seyahatnamesi: Istanbul, Yapı Kredi Yayınları, C. I, K. II, İstanbul 2003.

KARANOV, Maçarov, Naçov, Bulgar Gözüyle Istanbul, (Haz. Hüseyin Mevsim), Türk Tarih Kurumu, Ankara 2011.

KOLOĞLU, Orhan, Abdülhamit Gerçeği, Pozitif Yayıncılık, İstanbul 2005.

KURŞUN, Zekeriya- KAYSERiLioĞLU, Sertaç vd., Bâki Kente Âb-ı Bekâ: Hamidiye, İstanbul Büyükşehir Belediyesi Yayınları, İstanbul 2006, s. 51-71.

MARION - CRAWFORD, Francis, 1890'larda İstanbul, (Çev. Şeniz Türkömer), Türkiye İş Bankası Kültür Yayınları, İstanbul 2018.

MAZıOĞLU, Hasibe, Nedim, Kültür ve Turizm Bakanlığı Yayınları, Ankara 1988.

MillingEN, Alexander Van, istanbul, (Çev. Aykut Gürçağlar), Alkım Yayınevi, İstanbul 2003.

ORTAYLI, İlber, Osmanlı Imparatorluğu'nda Alman Nüfuzu, Kronik Kitap, İstanbul 2018.

OSMANOĞLU, Ayşe, Babam Sultan Abdülhamid, Timaş Yayınları, İstanbul 2019.

PARDOE, Julia, Sultanlar Şehri istanbul, (Çev. M. Banu Büyükkal), Türkiye İ̧̧ Bankası Kültür Yayınları, İstanbul 2017.

REFiK, Ahmet, Kafes ve Ferace Devrinde Istanbul, (Haz. Tahir Yücel), Kitabevi, İstanbul 1998.

Salih Münir Paşa, Geçmiş Zamanlar (II. Abdülhamid Devri Osmanlı Diplomasisi, Istanbul ve Paris Hatıraları), (Haz. Ali Birinci, Selma Günaydın), Türk Tarih Kurumu, Ankara 2015.

SCHRADER, Friedrich, Istanbul 100 Yıl Öncesine Bir Bakış, (Çev. Kerem Çalışkan), Remzi Kitabevi, İstanbul 2015.

SEMA, Sadri, Eski Istanbul Hatıraları, (Haz. Ali Şükrü Çoruk), Kitabevi, İstanbul 2002.

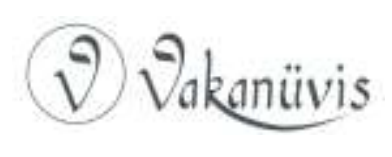


SONMEZER, Şükrü, ŞAHIN, Soner, "Hamidiye Su Terazisi Tarihi, Mimarisi, İşlevi”, Belleten, C. LXXVIII, S. 282, Ankara 2014, s.599-610.

Tahsin Paşa, Yıldız Hatıraları (Sultan II. Abdülhamit Han Devri Baş Mabeyni), (Haz. Ahmet Zeki İgöer), İz Yayıncılık, İstanbul 2018.

TEKÇAM, Mitat, Osmanlı Eğlence Kültüründe Mesire Yeri Olarak Kağıthane, Sakarya Üniversitesi Sosyal Bilimler Enstitüsü, Yayınlanmamış Yüksek Lisans Tezi, Sakarya 2006.

ÜNVER, A. Süheyl, "Her Devirde Kağıthane", Varlık Dergisi, S. 10, Ankara 1969, s. 435-460.

YASAMEE, Feroze A.K., Abdülhamid'in Dış Politikası Düvel-i Muazzama Karşısında Osmanlı 1878-1888, (Çev. Yusuf Selman İnanç), Kronik Kitap, İstanbul 2018. 


\section{Ekler}

Ek 1: Kâğıthane Mesiresinde Sultan II. Abdülhamid Tarafından İnşa Ettirilen Çeşme

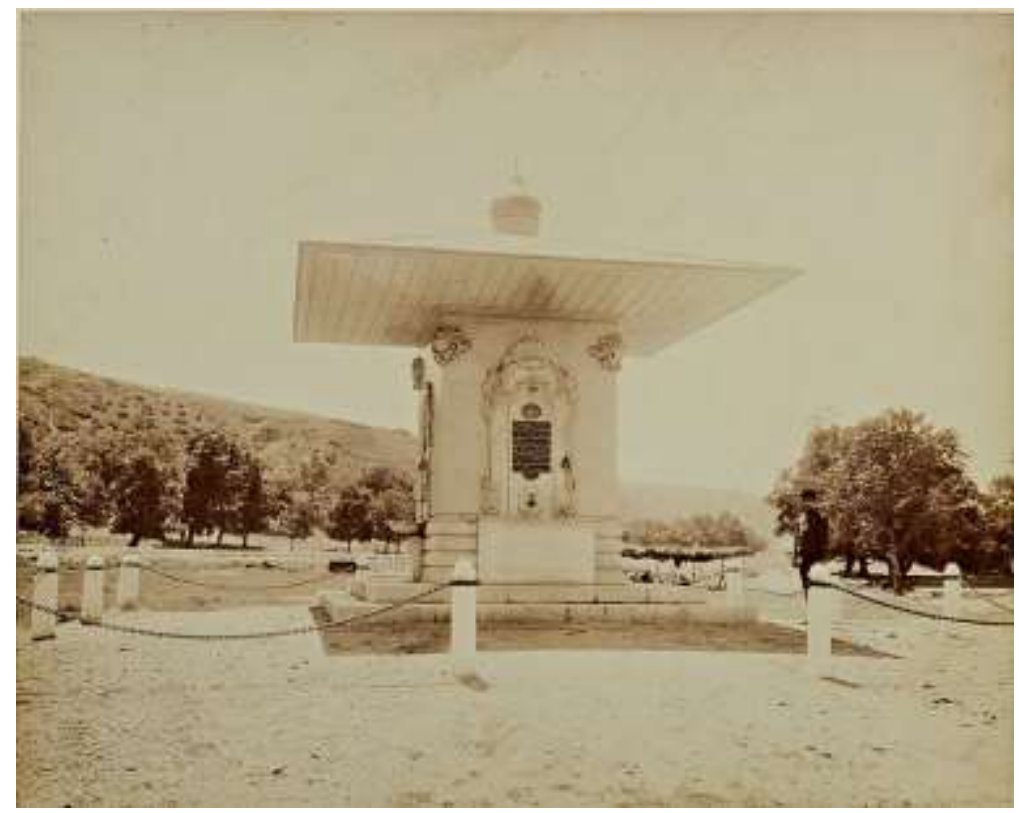

Kaynak: İstanbul Üniversitesi Nadir Eserler Kütüphanesi II. Abdülhamid Han Fotoğraf Albümleri Koleksiyonu, Yer Numarası: NEKYA90832/4. 
Ek 2: Kâğıthane Harasında Yetiştirilen Atlar

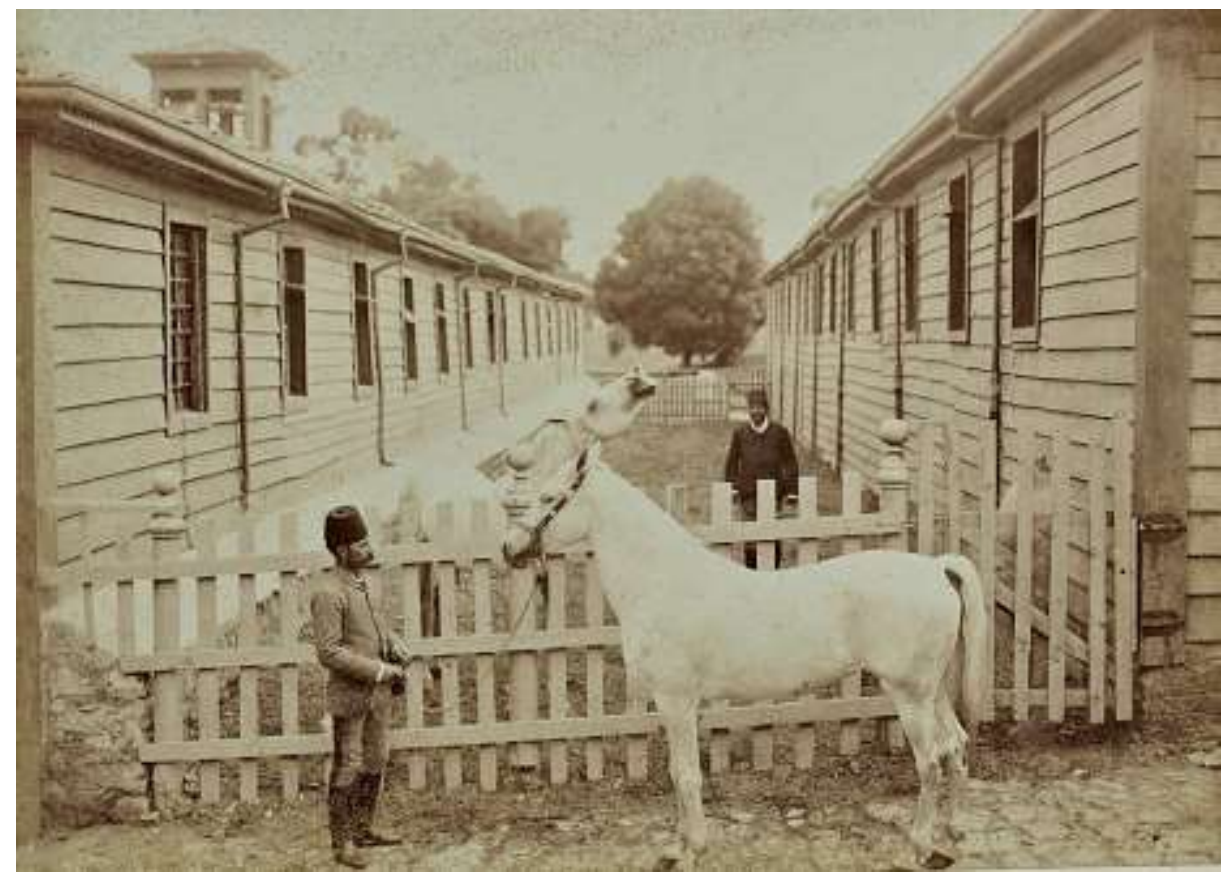

Kaynak: İstanbul Üniversitesi Nadir Eserler Kütüphanesi II. Abdülhamid Han Fotoğraf Albümleri Koleksiyonu, Yer Numarası: NEKYA90840/10. 
Ek 3: Kâğıthane Mesiresinde Düzenlenen Ziyafet Sırasında Mekteb-i Tıbbiye Talebeleri

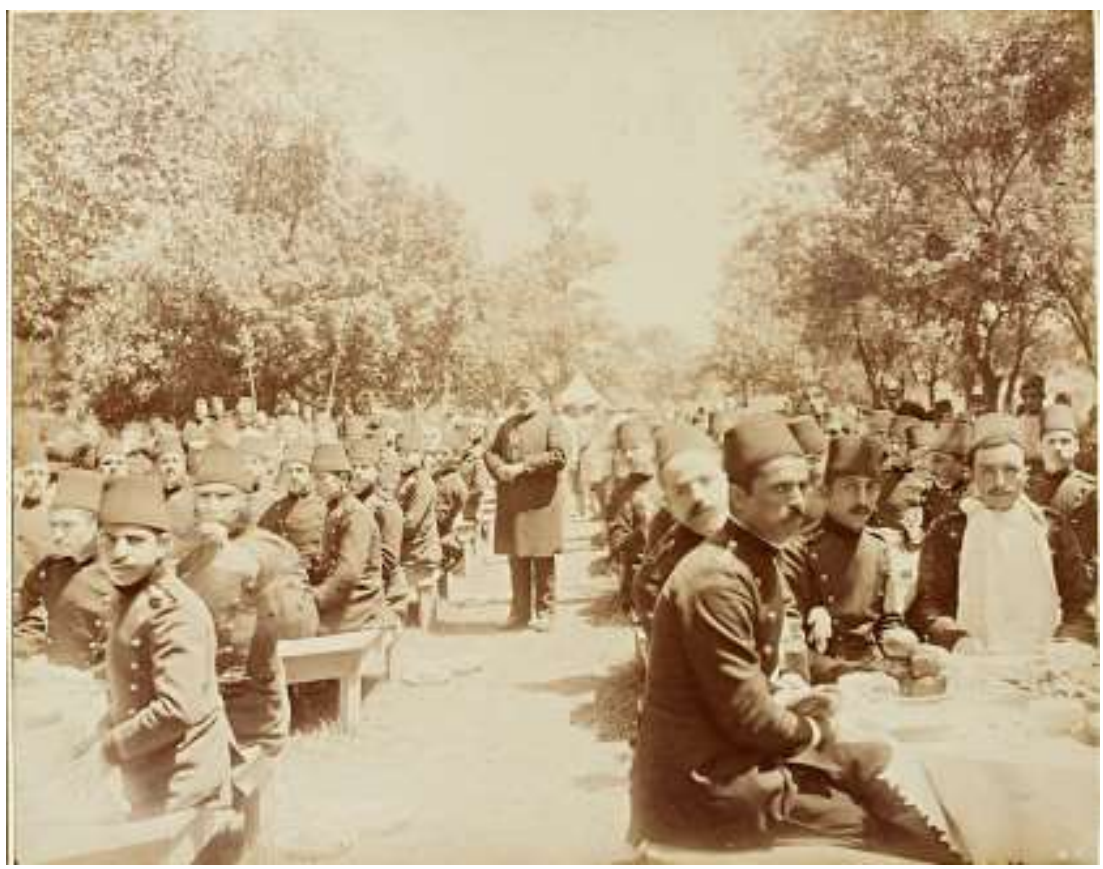

Kaynak: İstanbul Üniversitesi Nadir Eserler Kütüphanesi II. Abdülhamid Han Fotoğraf Albümleri Koleksiyonu, Yer Numarası: NEKYA90837/33. 
Ek 4: Kâğıthane Mesiresine Gelen Bahriye Mektebi Öğrencileri

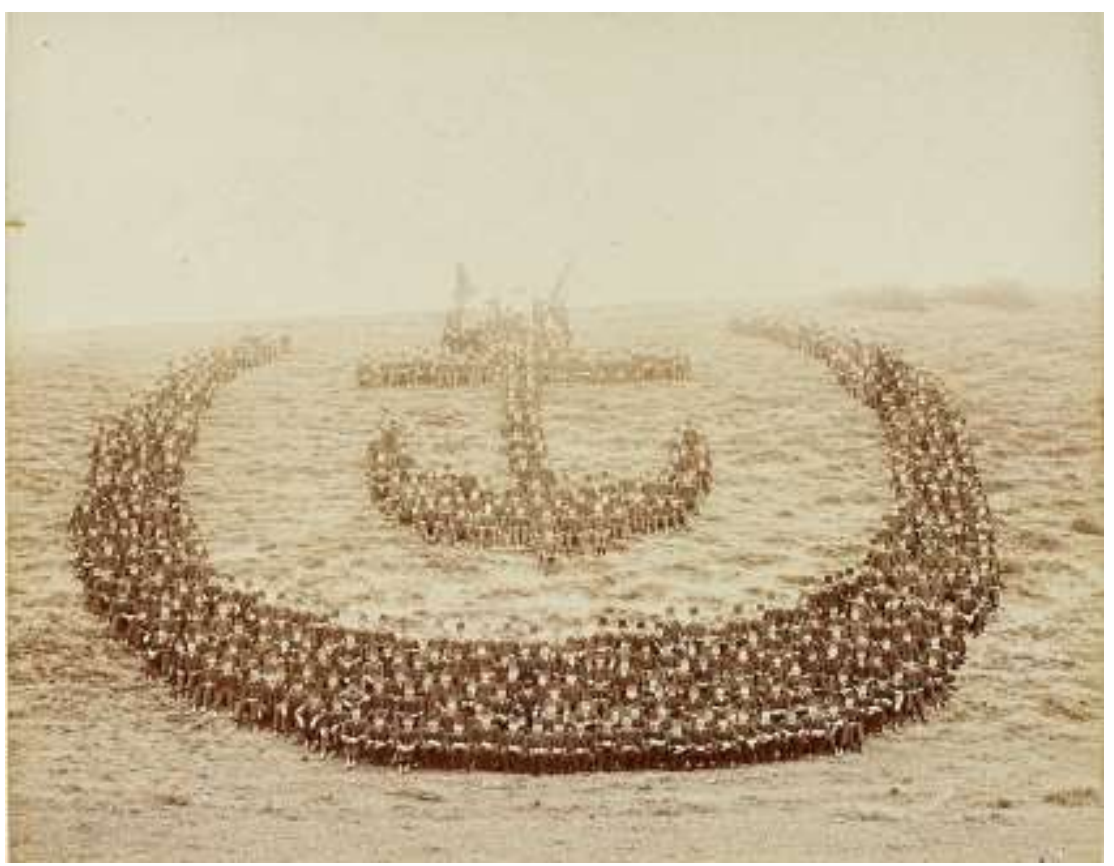

Kaynak: İstanbul Üniversitesi Nadir Eserler Kütüphanesi II. Abdülhamid Han Fotoğraf Albümleri Koleksiyonu, Yer Numarası: NEKYA90835/21. 
Ek 5: Kâğıthane Mesiresinde Düzenlenen Jimnastik Oyunları Sırasında Mekteb-i Sultânî Talebeleri

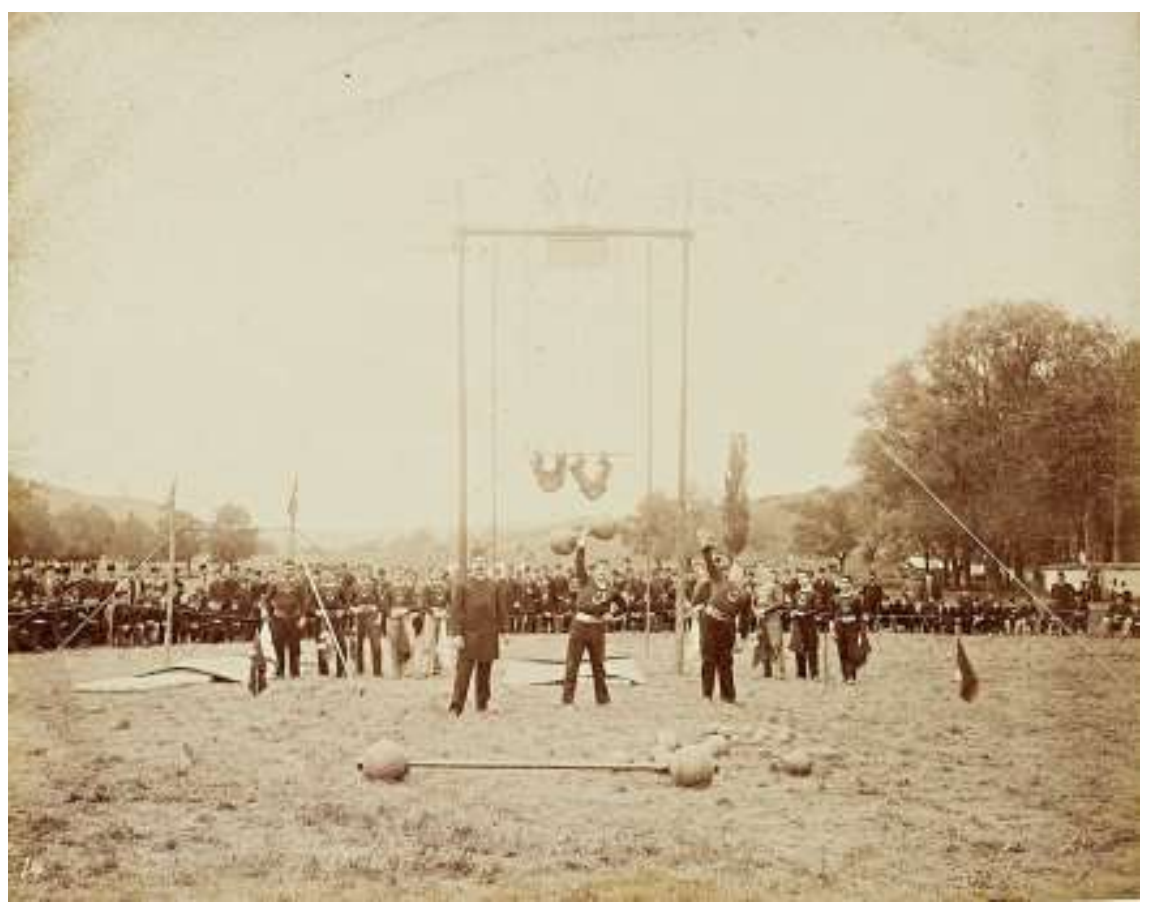

Kaynak: İstanbul Üniversitesi Nadir Eserler Kütüphanesi II. Abdülhamid Han Fotoğraf Albümleri Koleksiyonu, Yer Numarası: NEKYA90835/34. 